\title{
PENGARUH KEMASAN, KEWAJARAN HARGA DAN BRAND AWARENESS TERHADAP BRAND LOYALTY (STUDI KASUS PADA WISATAWAN NUSANTARA DI KARTIKA SARI BANDUNG)
}

\author{
A. Gima Sugiama \\ Emmanuel Febiano Sigit Bayu Pambudy \\ Politeknik Negeri Bandung \\ Universitas Kristen Maranatha \\ Email: Gima.Sugiama@gmail.com; joshuafebiano@gmail.com
}

Submitted: Apr 22, 2017; Reviewed: Apr 22, 2017; Accepted: May 12, 2017

\begin{abstract}
The competition of pastry business especially in Bandung is in rapid progress. Kartika Sari is one of the popular pastries brand in Bandung. Kartika Sari's pastry which is start from small medium enterprise has growth and well known by domestic tourist as one of the most wanted pastry in Bandung. One of the reason is because the owner start to apply the marketing elements correctly in their entrepeneurship. In other words, an integration between entrepreneurship and marketing (entrepreneurial marketing) has created an effectiveness in competition. However, the presence of competitors' brands with various packaging, heterogenous prices and different level of brand awareness could potentially affect the brand loyalty of domestic tourist to Kartika Sari's pastry brand. The purpose of this study is to determine the impact of packaging, price fairness and brand awareness to brand loyalty toward domestic tourist at Kartika Sari Bandung. The grand theory that used for the basis research were packaging, price and brand. The research method was descriptive method with quantitative research that processed by the regression model analysis techniques. The population study was domestic tourist whom were shopping at Kartika Sari Bandung. The technique of collecting data using questionnaires that distributed to a sample of 150 domestic tourist and who meet the eligibility rate of questionnaires was 110. The results showed that the packaging, the price fairness and brand awareness have significant positive impact to brand loyalty whether in parsial or simultanously. It means more quality in packaging tend to increase the brand loyalty of domestic tourist to Kartika Sari, more fairness in price tend to increase the brand loyalty of domestic tourist to Kartika Sari and the higher of brand awarness, result higher brand loyalty.
\end{abstract}

Keywords: packaging, price fairness, brand awareness and brand loyalty

\section{PENDAHULUAN}

Persaingan bisnis oleh-oleh makanan di Kota Bandung sedang mengalami kemajuan yang sangat pesat. Bisnis oleh-oleh makanan yang sebagian besar dimulai dari wirausaha kecil menengah tersebut kini berkembang dengan sangat cepat. Menurut Stokes (2000) berkembangnya suatu aktivitas kewirausahaan ternyata tidak lepas dari elemen-elemen pemasaran yang diterapkan dengan tepat, dengan kata lain terjadinya integrasi antara kewirausahaan dan elemen pemasaran (entrepreneurial marketing) dapat meningkatkan efektifitas bagi suatu aktivitas wirausaha. Faktor lain yang mendukung terjadinya persaingan bisnis oleh-oleh makanan tersebut adalah meningkatnya arus Wisatawan Nusantara yang berkunjung ke Kota Bandung pada akhir pekan atau juga pada hari libur. Melalui sumber CNN Indonesia tahun 2015, Dinas Kebudayaan dan Pariwisata (Disbudpar) Kota Bandung memaparkan bahwa Bandung menempati 
peringkat pertama sebagai kota wisata kuliner terpopuler di Indonesia dengan rata-rata jumlah Wisatawan Nusantara yang berkunjung ke Kota Bandung sebesar 6 juta orang per tahun.

Melalui fenomena yang dijumpai peneliti sehari-hari, ditemukan bahwa salah satu kebiasaan Wisatawan Nusantara yang berkunjung ke Kota Bandung adalah membeli oleh-oleh makanan. Ada begitu banyak jenis oleh-oleh makanan yang populer di Kota Bandung. Menurut sumber yang dipaparkan oleh Aneka Tempat Wisata pada tahun 2015, pisang bolen Kartika Sari ternyata menempati peringkat pertama sebagai oleh-oleh makanan yang paling populer di Bandung. Melalui hasil wawancara peneliti dengan 20 orang responden diketahui bahwa Kartika Sari termasuk merek pisang bolen yang paling populer, diikuti Prima Rasa sebagai pesaing terdekat kemudian Mayasari, Amanda Bolen dan Golden Leaf.

Bagi para Wisatawan Nusantara, beberapa atribut pemasaran seperti merek, harga dan kemasan termasuk hal yang penting untuk dipertimbangkan saat ingin membeli oleh-oleh. Para wisatawan tentu berharap bahwa oleh-oleh yang mereka beli memiliki kualitas kemasan yang baik agar saat sampai tempat tujuan masih tetap layak untuk dikonsumsi, bahkan tidak hanya kualitas kemasan yang baik, tetapi juga merek yang sudah dikenal agar lebih berkesan serta harga yang wajar.

Namun dengan munculnya berbagai merek bolen pesaing dengan kemasan yang beragam dan harga yang bervariasi serta tingkat brand awareness yang berbeda-beda memungkinkan adanya peluang bagi Wisatawan Nusantara untuk mencoba setiap merek yang ada, bahkan mungkin beralih ke merek yang baru. Dengan kata lain, adanya faktor tangible yang dapat direspon langsung oleh konsumen seperti kemasan, harga dan merek berpotensi mempengaruhi brand loyalty atau loyalitas merek konsumen.

Adanya fenomena tersebut menarik untuk dikaji mengenai pengaruh kemasan, kewajaran harga dan brand awareness terhadap brand loyalty (studi kasus pada Wisatawan Nusantara di toko kue Kartika Sari Bandung)."

\section{IDENTIFIKASI MASALAH}

Rumusan masalah yang dapat diajukan berdasarkan identifikasi masalah di atas adalah bagaimana pengaruh kemasan, kewajaran harga dan brand awareness terhadap brand loyalty baik secara parsial maupun serempak?

2

\section{TUJUAN PENELITIAN}

Tujuan peneliti melakukan penelitian ini adalah untuk mengetahui pengaruh kemasan, kewajaran harga dan brand awareness terhadap brand loyalty baik secara parsial maupun serempak.

\section{TINJAUAN PUSTAKA}

\section{Kemasan dan Jenis Kemasan}

Menurut Kent dan Omar dalam jurnal yang ditulis Dhurup, Mafini dan Dumasi (2014), kemasan adalah suatu wadah atau pembungkus (wrapper) untuk suatu produk. Proses mendesain, menciptakan serta membungkus produk dalam suatu kemasan dikenal dengan istilah pengemasan (Kotler, 2009).

Menurut Kotler (2010), kemasan dapat dibedakan menjadi tiga jenis yaitu :

1. Kemasan dasar (primary package)

Kemasan dasar adalah kemasan yang digunakan sebagai kemasan utama, yaitu kemasan yang bersentuhan langsung dengan produk inti. Contoh kemasan utama tersebut dapat berupa dus kecil, plastik, botol, sachet, kaleng, toples.

2. Kemasan tambahan (secondary package) Kemasan tambahan adalah kemasan yang melindungi dan membungkus kemasan dasar (primary package). Biasanya di kemasan ini dipakai sebagai media iklan dengan adanya corak karya seni yang melambangkan produk yang dikemasnya. Contoh kemasan tambahan yaitu : plastik ukuran sedang, dus ukuran sedang.

3. Kemasan pengiriman (shipping package) Kemasan pengiriman adalah kemasan yang digunakan untuk keperluan pengiriman dan penyimpanan. Jenis kemasan ini melindungi kemasan sekunder dan kemasan primer selama proses distribusi dari produsen ke konsumen. Contoh : barrel, container, karton box besar.

Setelah memahami pengertian tentang kemasan dan mengetahui jenis-jenis kemasan, maka selanjutnya akan dibahas mengenai kriteria kualitas suatu kemasan.

\section{Kualitas Kemasan}

Menurut Dhurup, Mafini dan Dumasi (2014) kualitas kemasan adalah aspek-aspek yang dinilai oleh konsumen pada kemasan yang dapat mempengaruhi konsumen dalam keputusan 
pembelian, misalnya seperti bentuk, bahan, warna, ukuran, logo serta daya tarik kemasan. Kualitas suatu kemasan dapat memicu suatu reaksi positif atau pun negatif dari konsumen yang dapat berpengaruh dalam keputusan pembelian konsumen (Aaker dalam Dhurup, Mafini \& Dumasi, 2014).

Untuk mendukung tujuan pengemasan dari masing-masing jenis kemasan seperti yang sudah diketahui sebelumnya, maka kemasan yang berkualitas perlu memenuhi suatu kriteria. Dalam jurnal yang ditulis Dhurup, Mafini dan Dumasi (2014) serta gagasan dari Jaswin. M (2008) kriteria sebuah kemasan yang berkualitas diantaranya :

1. Praktis

Kemasan yang berkualitas seharusnya memberikan kemudahan dalam penanganan, pengangkutan, distribusi, penyimpanan dan penyusunan / penumpukan.

2. Aman

Kemasan yang berkualitas seharusnya relatif kedap udara atau memiliki kemampuan untuk melindungi isi produk dari berbagai risiko eksternal misalnya perlindungan dari udara panas/dingin, sinar/cahaya matahari, bau asing, benturan/tekanan mekanis dan kontaminasi mikroorganisme.

3. Bersifat non toksik atau inert

Kemasan yang berkualitas seharusnya dapat mempertahankan warna, aroma dan cita rasa isi produk yang dikemas dan tidak bereaksi atau menyebabkan reaksi kimia.

4. Kedap air

Kemasan yang berkualitas seharusnya relatif mampu menahan air dalam tekanan tertentu sehingga air tidak dapat masuk ke dalam isi produk.

5. Tidak mudah bocor

Kemasan yang berkualitas seharusnya memiliki kerapatan bahan yang baik sehingga tidak mudah bocor.

6. Relatif tahan panas

Kemasan yang berkualitas seharusnya relatif tahan terhadap hawa panas dalam kondisi normal.

7. Efisien

Kemasan yang berkualitas seharusnya mudah dikerjakan secara massal dan harganya relatif murah.

8. Menarik

Kemasan yang berkualitas seharusnya mampu menciptakan daya tarik bagi konsumen. Dalam hal ini identifikasi, informasi dan penampilan seperti bentuk, warna dan keindahan bahan kemasan harus mendapatkan perhatian.

9. Ekonomis

Kemasan yang berkualitas seharusnya memenuhi persyaratan ekonomi, artinya kemampuan dalam memenuhi keinginan pasar, sasaran masyarakat dan tempat tujuan pemesan.

10. Terstandardisasi

Kemasan yang berkualitas seharusnya mempunyai ukuran, bentuk dan bobot yang sesuai dengan norma atau standar yang ada, mudah dibuang, dan di daur ulang.

Setelah mengetahui kriteria pengukuran kualitas suatu kemasan, maka selanjutnya akan dibahas mengenai indikator yang terdapat dalam kemasan.

\section{Indikator pada Kemasan}

Dalam jurnal yang diteliti oleh Dhurup, Mafini dan Dumasi (2014) tentang The Effect of packaging, price and brand awareness on brand loyalty, terdapat beberapa indikator pada kemasan yang dijelaskan sebagai berikut :

1. Bahan

Material / bahan yang digunakan relatif tidak mudah rusak dan sanggup menjaga isi kemasan. Bahan kemasan dapat berupa kertas, plastik, alumunium foil, botol dan logam.

2. Logo dan Label

Merek dagang, logo perusahaan dan label yang berisikan informasi produk sebaiknya tertera pada kemasan agar memudahkan konsumen dalam pencarian produk dan memberikan informasi yang lengkap tentang produk yang bersangkutan.

3. Warna

Warna adalah salah satu indikator pada kemasan yang sangat cepat direspon oleh visual konsumen, misalnya: kejelasan warna dan daya tarik warna kemasan.

4. Ukuran

Ukuran suatu kemasan pada umumnya disesuaikan dengan isi dari kemasan tersebut baik ukuran panjang, lebar, maupun tipis tebalnya.

5. Daya tarik desain kemasan

Sebaiknya kemasan suatu produk tidak hanya seimbang dari sisi bentuk dan fungsinya tetapi juga sanggup memberikan daya tarik bagi konsumen. 
Melalui penjelasan di atas, dapat diketahui bahwa terdapat 5 indikator dalam kemasan yang dapat dijadikan penilaian oleh konsumen untuk mengukur pengaruh kemasan pada brand loyalty.

\section{Kewajaran Harga}

Sebelum memahami tentang kewajaran harga maka terlebih dahulu perlu diketahui tentang konsep harga. Menurut Kotler (2010), harga adalah sejumlah uang yang dibayarkan untuk suatu produk dan jasa atau sejumlah nilai yang konsumen tukar untuk mendapatkan suatu manfaat dari produk dan jasa. Untuk beberapa produk seperti makanan, kewajaran harga dapat menjadi salah satu bahan pertimbangan konsumen dalam proses pengambilan keputusan pembelian bahkan menciptakan peluang untuk membangun loyalitas konsumen (Sahay, 2007).

Consuegra et al. (2007) mendefinisikan kewajaran harga sebagai suatu penilaian untuk suatu proses sehingga menciptakan hasil yang masuk akal dan dapat diterima. Aspek ini menunjukkan bahwa penilaian kewajaran harga melibatkan perbandingan prosedur harga yang terkait dengan standar, proses, nilai, referensi dan norma. Dalam jurnal yang diteliti oleh Dhurup, Mafini dan Dumasi (2014) dikatakan bahwa niat beli konsumen salah satunya dipengaruhi oleh harga yang wajar (fair), misalnya kewajaran dari sisi nilai produk, kualitas, brand, keterjangkauan, dan manfaat yang ingin ditawarkan melalui harga yang ada. Sesuai dengan penelitian ini menurut Consuegra et al. (2007) kewajaran harga dapat diukur dengan beberapa atribut sebagai berikut :

1. Pelanggan merasa membayar harga yang wajar pada setiap transaksi pembelian.

2. Pelanggan merasa wajar jika suatu produk yang sama jenisnya dari merek yang berbeda ditetapkan dengan harga yang berbeda.

3. Suatu harga dapat dikatakan wajar jika kebijakan harga yang ditentukan oleh perusahan dapat diterima oleh konsumen.

Harga yang ditetapkan merupakan sebuah etika, dengan indikasi bahwa pelanggan selalu diberitahu terlebih dahulu mengenai perubahan harga yang akan dilakukan oleh perusahaan sebelum harga yang baru ditetapkan.
Adanya atribut tersebut dapat membantu pelaku usaha untuk melihat kewajaran harga melalui persepsi konsumen.

\section{Strategi Penetapan Harga}

Strategi penetapan harga adalah suatu strategi atau metode yang diambil oleh seorang pelaku usaha dalam menentukan harga yang wajar pada suatu barang dan jasa untuk memenangkan persaingan. Berikut ini adalah penjelasan masing-dari masing strategi penetapan harga (Kotler, 2010) :

\section{Premium Pricing}

Premium pricing adalah penetapan harga tinggi untuk suatu produk karena produk tersebut termasuk ke dalam specialty product atau produk mewah atau produk tersebut memberikan manfaat dan nilai lebih dari produk biasanya.

2. Penetration Pricing

Penetapan harga suatu produk yang lebih rendah dari pesaing dengan tujuan agar produk tersebut dapat merebut market share pesaing.

3. Economy Pricing

Penetapan harga yang terjadi dengan menekan biaya produksi dan pemasaran sehingga menciptakan persepsi harga yang lebih murah.

4. Skimming Price

Penetapan suatu harga produk di atas harga pasar karena produk tersebut memiliki ciri khas, keunikan atau keunggulan brand awareness.

5. Psychological Pricing

Suatu harga yang ditetapkan oleh pelaku usaha yang ditujukan untuk menarik perhatian konsumen secara psikologis, misalnya : harga produk Rp. 9,999.tampak lebih murah dan menarik perhatian jika dibandingkan harga yang tertera Rp. 10,000.-.

6. Product Bundle Pricing

Pelaku usaha menetapkan harga untuk suatu gabungan produk, biasanya harga yang ditetapkan lebih murah jika dibandingkan dijual terpisah. Strategi ini dilakukan untuk mengurangi stok yang berlebih di gudang atau untuk menarik pembelian konsumen.

7. Promotional Pricing

Penetapan harga yang dilakukan dengan tujuan untuk promosi atau memicu penjualan jangka pendek. Strategi ini umum dilakukan untuk suatu produk 
baru yang belum dikenal oleh konsumen.

8. Geographical Pricing

Penetapan harga berdasarkan area atau lokasi pengiriman. Harga yang yang terjadi dapat berbeda-beda bergantung kepada biaya angkut dan transportasi serta kondisi demografis dan psikografis wilayah yang bersangkutan.

Hal yang penting dalam menentukan strategi penetapan harga yang tepat adalah pelaku usaha perlu terlebih dahulu mengenal keunggulan produknya dan target yang ingin dicapai.

\section{Indikator Kewajaran Harga}

Indikator yang digunakan untuk mengukur kewajaran harga, diadaptasi dari studi yang dilakukan oleh Dhurup, Mafini dan Dumasi (2014), yaitu sebagai berikut:

1. Keterjangkauan harga

Konsumen merasa bahwa harga yang tertera pada produk sesuai dengan daya beli yang mereka miliki.

2. Kesesuaian harga dengan kualitas produk

Konsumen merasa bahwa kualitas yang mereka terima sesuai dengan harga yang mereka bayarkan.

3. Kesesuaian harga dengan merek Konsumen merasa bahwa harga yang mereka bayar sesuai dengan merek produk yang bersangkutan.

4. Kepuasan harga

Konsumen merasa puas dengan harga produk setelah melakukan konsumsi dan evaluasi produk.

Melalui penjelasan di atas, dapat diketahui bahwa terdapat 4 indikator pada harga yang dapat dijadikan penilaian oleh konsumen untuk mengukur pengaruh kewajaran harga pada brand loyalty.

\section{Brand Awareness}

Menurut Aaker (2000), brand awareness atau kesadaran merek adalah kemampuan dari pelanggan potensial untuk mengenali dan mengingat suatu merek dalam kategori tertentu. Brand awareness atau kesadaran akan suatu merek merupakan salah satu variabel yang penting untuk membangun sebuah brand loyalty. Aspek paling penting dari brand awareness adalah bentuk informasi dalam ingatan di tempat pertama seorang konsumen.

\section{Tingkatan Brand Awareness}

Kemampuan pelanggan untuk mengenali atau mengingat merek suatu produk berbeda-beda, bergantung kepada tingkat komunikasi suatu merek atau persepsi konsumen terhadap merek yang ditawarkan. Oleh karena itu seorang pelaku usaha perlu mengetahui tingkatan brand awareness konsumennya untuk menentukan strategi yang tepat. Berikut ini adalah penjelasan tentang tingkatan brand awareness :

\section{Unware of brand}

Tingkat yang paling rendah dalam piramida kesadaran merek, dimana konsumen tidak menyadari adanya suatu merek tertentu.

\section{Brand recognition}

Pada tingkat ini, konsumen mengetahui keberadaan suatu merek. Dalam piramida brand awareness, brand recognition menunjukkan level minimum brand awareness seorang konsumen terhadap suatu produk. Hal ini penting karena merupakan langkah awal saat seorang pembeli akan memilih suatu merek dalam proses pembelian.

3. Brand recall

Pada level ini, konsumen tidak hanya mengetahui tentang keberadaan suatu merek tetapi ingat akan merek tersebut walaupun tanpa menggunakan bantuan atau tanda-tanda.

4. Top of Mind

Pada level ini, suatu merek menjadi pilihan utama atau merek tersebut adalah merek yang pertama kali muncul dalam benak konsumen. Merek tersebut menjadi merek utama dari berbagai merek yang ada di dalam benak konsumen.

\section{Indikator Brand Awareness}

Indikator yang digunakan untuk mengukur brand awareness diadaptasi dari studi yang dilakukan oleh Dhurup, Mafini dan Dumasi (2014), yaitu sebagai berikut :

\section{Recall}

Seberapa jauh konsumen dapat mengingat

ketika ditanya merek apa saja yang mereka ingat.

\section{Recognition}

Seberapa jauh konsumen dapat mengenali merek tersebut dalam satu kategori tertentu.

\section{Purchase decision}


Seberapa jauh konsumen akan memasukkan suatu merek ke dalam alternatif

pilihan ketika mereka akan membeli produk atau layanan.

4. Consumption

Konsumen membeli suatu merek karena merek tersebut sudah menjadi top of mind konsumen.

Melalui penjelasan di atas, dapat diketahui bahwa terdapat 4 indikator pada brand awareness yang dapat dinilai oleh konsumen untuk mengukur pengaruh brand awarenes pada brand loyalty.

\section{Brand Loyalty}

Menurut Aaker (2000), brand loyalty adalah suatu ukuran keterkaitan pelanggan kepada sebuah merek. Ukuran ini mampu memberikan gambaran tentang mungkin tidaknya seorang pelanggan beralih ke merek lain yang ditawarkan oleh pesaing, terutama jika pada merek tersebut didapati adanya perubahan, baik menyangkut kemasan, harga ataupun atribut lainnya.

Brand Loyalty atau loyalitas merek merupakan faktor yang penting untuk diperhatikan oleh pelaku wirausaha karena konsumen yang loyal merupakan salah satu faktor yang mendukung eksistensi suatu wirausaha.

\section{Tingkatan Brand Loyalty}

Untuk lebih mengetahui level atau tingkatan pada brand loyalty, selanjutnya akan dibahas mengenai tingkatan loyalitas merek. Menurut Rangkuti (2002) terdapat beberapa tingkatan loyalitas merek yang dapat dijelaskan sebagai berikut. :

1. Switcher yaitu konsumen yang suka berpindah-pindah produk (level loyalitas merek paling rendah).

2. Habitual buyer adalah pembeli yang bersifat kebiasaan.

3. Satisfied buyer atau pembeli yang puas.

4. Likes the brand buyers atau pembeli yang membeli suatu produk karena menyukai merek produk tersebut.

5. Commited buyer atau pembeli yang sudah komitmen kepada suatu produk (level paling tinggi dalam piramida loyalitas merek).

\section{Indikator pada Brand Loyalty}

Indikator yang digunakan untuk mengukur brand loyalty diadaptasi dari studi yang dilakukan oleh Dhurup, Mafini dan Dumasi (2014), yaitu sebagai berikut :

1. Prilaku atau Kebiasaan

Loyalitas merek terbentuk karena suatu pola pembelian konsumen yang sudah menjadi kebiasaan.

2. Liking the brand

Konsumen loyal dengan suatu merek karena menyukai merek tersebut dan merasa nyaman dengan merek tersebut.

3. Kepuasan

Loyalitas terhadap merek terjadi karena konsumen puas dengan merek tersebut.

4. Komitmen

Konsumen enggan beralih ke merek pesaing karena sudah komitmen dengan merek yang dikonsumsinya.

Melalui penjelasan di atas, dapat diketahui bahwa terdapat 4 indikator yang dapat dijadikan penilaian oleh konsumen untuk mengukur brand loyalty.

\section{Rerangka Pemikiran dan Model Penelitian}

Persaingan industri makanan khususnya oleholeh makanan di Kota Bandung sedang meningkat pesat. Munculnya para pesaing Kartika Sari dengan kemasan yang beragam serta harga yang bervariasi dan tingkat perbedaan brand awareness dapat berpotensi mempengaruhi brand loyalty Wisatawan Nusantara pada Kartika Sari.

Adanya fenomena tersebut, menarik peneliti untuk mengetahui lebih jauh apakah ketiga variabel tersebut mempengaruhi brand loyalty Wisatawan Nusantara yang berkunjung ke Kartika Sari Bandung.

Berdasarkan rerangka pemikiran, maka diperoleh model penelitian sebagai berikut:

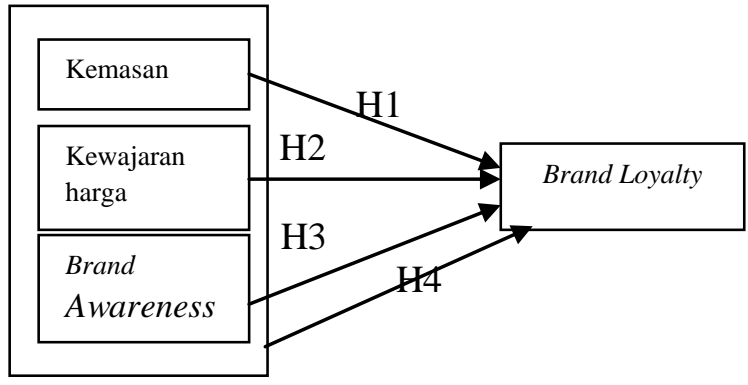

Gambar 1 Model Penelitian 


\section{HIPOTESIS PENELITIAN}

Berdasarkan landasan teori dan model penelitian yang digunakan maka hipotesis penelitian yang dapat diajukan adalah :

H1: Kemasan berpengaruh positif signifikan terhadap brand loyalty.

$\mathrm{H} 2$ : Kewajaran Harga berpengaruh positif signifikan terhadap brand loyalty.

H3: Brand Awareness berpengaruh positif signifikan terhadap brand loyalty.

H4: Kemasan, Kewajaran Harga dan Brand Awareness berpengaruh positif signifikan terhadap Brand Loyalty.

\section{METODE PENELITIAN}

Metode yang digunakan dalam penelitian ini adalah metode kuantitatif dengan teknik self administer survey yaitu penelitian yang menekankan pada teknik kuantifikasi dari data yang terkumpul melalui wawancara atau kuesioner yang kemudian diolah dengan menggunakan angka-angka sebagai data untuk dianalisis secara statistik (Sugiama, 2008). Data yang sudah diolah kemudian dipaparkan secara deskriptif dan disimpulkan berdasarkan faktafakta pada masa penelitian berlangsung atau masa sekarang. Rumusan masalah yang digunakan dalam penelitian ini bersifat asosiatif kausal yaitu hubungan sebab akibat dimana ada variabel independen atau variabel yang mempengaruhi dan variabel dependen atau variabel yang dipengaruhi (Uma Sekaran, 2009:110).

\section{Populasi}

Populasi dalam penelitian ini adalah Wisatawan Nusantara yang berbelanja di Kartika Sari Bandung. Menurut Sugiama (2008), populasi adalah sekumpulan dari individu yang memiliki karakteristik tertentu dengan ciri-ciri yang cenderung mirip atau sama, dalam kasus ini populasi yang dipilih yaitu Wisatawan Nusantara dengan usia produktif antara $20-65$ tahun yang sedang berbelanja di Kartika Sari Bandung, khususnya di Kartika Sari cabang H. Akbar, Kebon Kawung dan Dago yang umumnya dipadati oleh Wisatawan Nusantara. Populasi konsumen kue pastry yang diteliti yaitu infinit, artinya jumlah kedatangan konsumen dalam suatu toko kue selalu berubah-ubah (Sugiama, 2008). Adanya keterbatasan yang dihadapi peneliti baik dari segi waktu, tenaga dan biaya, maka peneliti hanya akan mengambil sampel dari populasi yang akan diteliti. Adapun karakteristik anggota populasi sebagai berikut :

1. Merupakan Wisatawan Nusantara

2. Sedang berbelanja di Kartika Sari Bandung baik di cabang H. Akbar, Dago maupun Kebon Jukut.

3. Berusia produktif 20-65 tahun.

\section{Teknik Pengambilan Sampel}

Menurut Sugiama (2008), sampel adalah suatu bagian yang diambil dari sebuah populasi. Sampel dalam penelitian ini adalah bagian dari populasi Wisatawan Nusantara yang sedang berkunjung ke Toko Kue Kartika Sari Bandung.

Teknik pengambilan sampel yang digunakan dalam penelitian ini adalah menggunakan pendekatan nonprobability sampling dengan metode judgement sampling. Nonprobability sampling artinya sampel yang diambil dari sebuah populasi yang didasarkan pada pertimbangan tertentu yang tidak membuka kemungkinan bagi semua individu dalam populasi dapat terpilih menjadi anggota sampel (Sugiama, 2008). Judgement sampling adalah penarikan sampel yang terlebih dahulu menentukan kriteria responden yang lebih spesifik (Sugiama, 2008). Dalam kasus ini sampel yang dipilih adalah konsumen Wisatawan Nusantara yang sedang berbelanja di Toko Kue Kartika Sari Bandung.

Dengan menggunakan rumus yang dikemukakan Paul Leedy dalam Margono (2003), maka jumlah sampel yang didapatkan adalah 97. Namun diputuskan untuk mengambil anggota sampel sebanyak 150, dengan mempertimbangkan apabila ada yang hilang atau tidak memenuhi syarat.

\section{PEMBAHASAN HASIL PENELITIAN Uji Validitas dan Reliabilitas}

Berdasarkan hasil uji validitas dengan teknik Pearson Correlation untuk variabel kemasan, kewajaran harga, brand awareness dan brand loyalty maka didapatkan hasil sebagai berikut :

\section{Kemasan}

Melalui 10 butir pernyataan yang ada, ternyata diketahui bahwa kesepuluh pernyataan tersebut memenuhi uji validitas karena memiliki nilai $r$ (korelasi) lebih dari (>) 0,3 dan nilai signifikan kurang dari $(<) 0,05$.

\section{Kewajaran Harga}

Melalui 6 butir pernyataan yang ada, ternyata diketahui bahwa keenam pernyataan tersebut memenuhi uji validitas karena memiliki nilai $r$ 
(korelasi) lebih dari (>) 0,3 dan nilai signifikan kurang dari $(<) 0,05$.

\section{Brand Awareness}

Melalui 8 butir pernyataan yang ada, ternyata diketahui bahwa kedelapan pernyataan tersebut memenuhi uji validitas karena memiliki nilai $r$ (korelasi) lebih dari (>) 0,3 dan nilai signifikan kurang dari $(<) 0,05$.

\section{Brand Loyalty}

Melalui 8 butir pernyataan yang ada, ternyata diketahui bahwa kedelapan pernyataan tersebut memenuhi uji validitas karena memiliki nilai $r$ (korelasi) lebih dari (>) 0,3 dan nilai signifikan kurang dari $(<) 0,05$.

Tahap selanjutnya adalah pengujian reliabilitas. Dalam tahap reliabilitas ini hanya item pernyataan yang telah valid saja yang bisa masuk ke tahap uji reliabilitas. Pengujian reliabilitas dilakukan dengan teknik Cronbach Alpha, Kriteria variabel yang diteliti telah reliabel ketika nilai Cronbach Alpha lebih besar (>) 0,60.

Setelah dihitung melalui SPSS 20 diketahui bahwa keempat variabel yaitu kemasan, kewajaran harga, brand awareness dan brand loyalty adalah reliabel karena memiliki nilai Cronbach Alpha lebih besar $(>0,60)$ yaitu 0,$820 ; 0,847 ; 0,852$ dan 0,886

\section{Uji Asumsi Klasik}

Uji asumsi klasik terdiri atas tiga tahap yang terdiri dari uji normalitas, uji multikolinearitas dan uji heteroskedastisitas. Uji normalitas dilakukan untuk menguji apakah data tersebut berdistribusi normal. Uji normalitas dalam penelitian ini menggunakan teknik one sample Kolmogorov Smirnov. Kriteria yang harus dipenuhi untuk data dikatakan normal adalah nilai sig pada residual lebih besar $(>)$ daripada $\alpha$ yang dikehendaki, Taraf nyata $(\alpha)$ yang digunakan dalam penelitian ini adalah 5\%. Hasil uji normalitas data ditampilkan pada tabel 5.7 sebagai berikut :

Tabel 1 Hasil Uji Normalitas

\begin{tabular}{l}
\hline Keterangan $\frac{\text { Value }}{}$ \\
\hline Assym sig (2 tailed) 0,264 \\
\hline Sumber : Hasil Pengolahan Peneliti dengan IBM \\
SPSS 20 \\
Melalui tabel menunjukkan bahwa data \\
berdistribusi normal karena memiliki nilai \\
signifikansi lebih besar $(>)$ tingkat kesalahan $(\alpha)$ \\
5\% yaitu 0,264 \\
8
\end{tabular}

Selanjutnya uji multikolinearitas dilakukan untuk menguji apakah data yang diteliti terbebas dari multikolinearitas atau dengan kata lain apakah antara variabel independen terdapat hubungan. Data yang baik adalah data yang terbebas dari multikolinearitas. Kriteria yang harus dipenuhi untuk data dikatakan bebas multikolinearitas adalah nilai VIF $<10$ dan Tolerance $>0,10$. Hasil pengujian multikolinearitas ditampilkan pada tabel 2 sebagai berikut :

Tabel 2 Hasil Pengujian Multikolinearitas

\begin{tabular}{lll}
\hline Variabel & Tolerance & VIF \\
\hline Kemasan & 0,696 & 1,437 \\
$\begin{array}{l}\text { Kewajaran } \\
\text { Harga }\end{array}$ & 0,637 & 1,570 \\
$\begin{array}{l}\text { Brand } \\
\text { awareness }\end{array}$ & 0,691 & 1,448 \\
\hline $\begin{array}{l}\text { Dependent variable: Brand loyalty } \\
\text { (Sumber : Hasil Pengolahan IBM SPSS 20) }\end{array}$
\end{tabular}

Melalui hasil tabel 2 menunjukkan bahwa data terbebas dari multikolinearitas karena memiliki nilai Tolerance $>0,1$ dan VIF $<10$.

Kemudian uji berikutnya adalah uji heteroskedastisitas. Jika variance dari residual satu pengamatan ke pengamatan yang lain tetap maka disebut homoskedastisitas dan jika berbeda disebut heteroskoedastisitas. Model regresi yang baik adalah yang homoskedastisitas (Ghozali, 2009). Data dikatakan terbebas heteroskedastisitas ketika signifikan variabel independen lebih besar (>) dari taraf nyata (5\%). Berikut pada tabel 5.8 ditampilkan hasil pengujian heteroskedastisitas metode Spearman Rho:

Tabel 3 Hasil Uji Heteroskedastisitas

\begin{tabular}{ll}
\hline Variabel & Assym sig \\
\hline Kemasan & 0,291 \\
Kewajaran Harga & 0,875 \\
Brand awareness & 0,847 \\
\hline
\end{tabular}

Melalui hasil tabel 3 menunjukkan bahwa data terbebas dari heteroskedastisitas karena memiliki nilai signifikan lebih besar (>) dari taraf nyata 5 $\%$ yaitu sebesar 0,$291 ; 0,875 ; 0,847$.

\section{Uji Hipotesis}

Sesuai dengan tujuan penelitian untuk mengetahui pengaruh kemasan, kewajaran harga dan brand awareness terhadap brand loyalty, maka dilakukan pengujian menggunakan uji 
regresi berganda dengan menggunakan bantuan SPSS.

Tabel 4 Hasil Uji R Square

\begin{tabular}{lrrrr}
\hline \multicolumn{4}{c}{ Model Summary } \\
Model & R & R Square & $\begin{array}{c}\text { Adjusted R } \\
\text { Square }\end{array}$ & $\begin{array}{r}\text { Std. Error of } \\
\text { the Estimate }\end{array}$ \\
\hline 1 & & .594 & 2.90827 \\
a. Predictors: (Constant), BA, KK, KH &
\end{tabular}

Nilai $\mathrm{R}$ dalam perhitungan regresi penelitian ini adalah sebesar 0,778. Apabila nilai $\mathrm{R}$ di atas 0,600 maka dapat disimpulkan terdapat hubungan yang kuat antara variabel independen (X) dan variabel dependen (Y). Kemudian nilai Adjusted R Square sebesar 0,594 atau 59,4\% menunjukan bahwa kemasan, kewajaran harga dan brand awareness memiliki kontribusi sebesar 59,4\% terhadap brand loyalty sedangkan sisanya sebesar $40,6 \%$ dipengaruhi oleh variabel lain yang tidak dimasukan di dalam model penelitian ini seperti variabel product quality, place, promotion, dan lain-lain (Dhurup, Mafini, Dumasi, 2014).

Tabel 5 Hasil Uji t

\begin{tabular}{|c|c|c|c|c|c|c|}
\hline \multirow{2}{*}{\multicolumn{2}{|c|}{ Model }} & \multicolumn{2}{|c|}{$\begin{array}{l}\text { Unstandardized } \\
\text { Coefficients }\end{array}$} & \multirow{2}{*}{$\begin{array}{c}\text { Std. Coef. } \\
\text { Beta }\end{array}$} & \multirow[t]{2}{*}{$\mathrm{t}$} & \multirow[t]{2}{*}{ Sig. } \\
\hline & & B & $\begin{array}{l}\text { Std. } \\
\text { Error }\end{array}$ & & & \\
\hline \multirow{4}{*}{1} & (Cons) & -2.479 & 2.811 & & -.882 & .380 \\
\hline & KK & .210 & .077 & .200 & 2.737 & .007 \\
\hline & $\mathrm{KH}$ & .382 & .119 & .245 & 3.209 & .002 \\
\hline & BA & .509 & .076 & .493 & 6.713 & .000 \\
\hline
\end{tabular}

Melalui hasil perhitungan menggunakan SPSS 20, pada tabel 5 di kolom standardized coefficients dapat diketahui nilai Beta dari masing-masing variabel independen yang menunjukkan besar pengaruh masing-masing variabel independen terhadap variable dependen. Melalui tabel 5 tersebut diketahui bahwa brand awareness memiliki pengaruh paling besar $(0,493)$ terhadap brand loyalty dibandingkan variabel independen lainnya seperti kemasan $(0,200)$ dan kewajaran harga $(0,245)$.

Melalui tabel 5 di atas dapat diketahui nilai t yang dipakai untuk mengetahui apakah variabel-variabel independen berpengaruh secara signifikan terhadap variable dependen. Nilai $t$ tersebut selanjutnya dilakukan perbandingan dengan $\mathrm{t}$ tabel. Nilai $\mathrm{t}$ tabel dihitung dengan cara menentukan nilai $\mathrm{a}=5 \%: 2=2.5 \%$ (uji dua sisi) dengan derajat kebebasan (df) n-k-1 sebesar 106, dimana $\mathrm{n}$ adalah jumlah sampel dan $\mathrm{k}$ adalah jumlah independen variabel. Nilai $\mathrm{t}$ tabel diperoleh dengan menggunakan bantuan program Microsoft Excel dan diketahui nilai t tabel adalah 1,98, karena masing-masing nilai t hitung lebih besar dari $t$ tabel yaitu :

1. kemasan ( $t$ hitung 2,737 $>\mathrm{t}$ tabel 1,98)

2. kewajaran harga ( $\mathrm{t}$ hitung 3,209 > t tabel 1,98)

3. brand awareness ( $\mathrm{t}$ hitung 6,713 > t tabel $1,98)$

maka dapat disimpulkan bahwa terdapat pengaruh yang signifikan dari variabel independen terhadap variabel dependen.

Selanjutnya melalui pengolahan SPSS juga dapat diketahui beberapa indikator yang dapat tersusun menjadi sebuah persamaan regresi yaitu:

$\mathrm{Y}=-2,479+0,210 \mathrm{X} 1+0,382 \mathrm{X} 2+0,509 \mathrm{X} 3+\mathrm{e}$

Pada hasil penelitian diketahui nilai konstanta sebesar $-2,479$. Hal ini menunjukan bahwa nilai variabel dependen tanpa dipengaruhi oleh variabel independen adalah sebesar -2,479 artinya tanda negatif pada konstanta tersebut menjelaskan bahwa tanpa ada kemasan, harga yang wajar dan brand awareness maka konsumen sudah beralih ke merek lain. Kemudian koefisien regresi variabel kemasan sebesar 0,210 memiliki arti bahwa jika variabel independen lain diasumsikan nilainya tetap dan kemasan mengalami peningkatan kualitas sebesar 1\%, maka brand loyalty konsumen akan mengalami gambaran kenaikan sebesar 0,210, artinya semakin tinggi kualitas kemasan maka brand loyalty konsumen cenderung semakin tinggi. Kemudian koefisien regresi variabel kewajaran harga sebesar 0,382 memiliki arti bahwa jika diasumsikan variabel independen lain nilainya tetap dan harga mengalami peningkatan kewajaran sebesar $1 \%$, maka brand loyalty konsumen akan mengalami gambaran kenaikan sebesar 0,382, artinya semakin wajar harga yang ditetapkan maka semakin tinggi brand loyalty konsumen. Selanjutnya koefisien regresi variabel brand awareness sebesar 0,509 memiliki arti bahwa jika variabel independen lain diasumsikan nilainya tetap dan brand awareness mengalami peningkatan sebesar 1\%, maka brand loyalty konsumen akan mengalami gambaran kenaikan sebesar 0,509 artinya semakin tinggi brand awareness maka brand loyalty konsumen cenderung semakin tinggi. 
Pengaruh Kemasan Terhadap Brand Loyalty

Pada tahap terakhir, peneliti melakukan pengujian hipotesis. Hasil uji masing-masing hipotesis tersebut dijelaskan berikut ini :

Hipotesis pertama bertujuan untuk menguji pengaruh kemasan terhadap brand loyalty yang dituliskan sebagai berikut :

$H O$ : kemasan $\left(\mathrm{x}_{1}\right)$ tidak berpengaruh positif terhadap brand loyalty $(y)$

H1: kemasan $\left(\mathrm{x}_{1}\right)$ berpengaruh positif terhadap brand loyalty $(y)$

Hasil uji hipotesis dengan regresi linier berganda menunjukkan nilai signifikan sebesar 0.007 (kurang dari $5 \%$ ) atau t hitungnya sebesar 2,737 (di atas 1,98). Hal tersebut dinilai dari masingmasing indikator kemasan seperti bahan, logo dan label, warna, ukuran serta daya tarik desain kemasan.

Dengan demikian pada kasus ini dapat disimpulkan bahwa kemasan berpengaruh positif signifikan terhadap brand loyalty, artinya kemasan yang semakin berkualitas cenderung membuat brand loyalty semakin tinggi.

\section{Pengaruh Kewajaran Harga Terhadap Brand Loyalty}

Hipotesis kedua bertujuan untuk menguji pengaruh kewajaran harga secara terhadap brand loyalty yang dituliskan sebagai berikut :

$H O$ : kewajaran harga $\left(\mathrm{x}_{2}\right)$ tidak berpengaruh positif terhadap brand loyalty $(y)$

$H 1$ : kewajaran harga $\left(\mathrm{x}_{2}\right)$ berpengaruh positif terhadap brand loyalty $(y)$

Hasil uji hipotesis dengan regresi linier berganda menunjukkan nilai signifikan sebesar 0,002 (kurang dari $5 \%$ ) atau t hitungnya sebesar 3,209 (di atas 1,98). Hal tersebut dinilai dari masingmasing indikator kewajaran harga seperti keterjangkauan harga, kesesuaian harga dengan kualitas produk, kesesuaian harga dengan manfaat, kepuasan harga.

Dengan demikian pada kasus ini dapat disimpulkan bahwa kewajaran harga berpengaruh positif signifikan terhadap brand loyalty, artinya harga kue yang semakin wajar cenderung membuat brand loyalty semakin tinggi. Pernyataan ini

didukung oleh penelitian sebelumnya oleh Dhurup, Mafini, Dumasi (2014) yang menjelaskan bahwa ketika konsumen dikenakan harga yang mahal dibandingkan harga pesaing maka konsumen akan menilai bahwa fasilitas yang akan mereka terima akan sebanding dengan harga yang mereka bayarkan. Fasilitas tersebut dapat berupa keunggulan pelayanan, keunggulan merek, keunggulan produk, keunggulan lokasi, dan lain-lain.

\section{Pengaruh Brand Awareness Terhadap Brand Loyalty}

Hipotesis ketiga bertujuan untuk menguji pengaruh brand awareness terhadap brand loyalty yang dituliskan sebagai berikut :

$H O$ : Brand awareness $\left(\mathrm{x}_{3}\right)$ tidak berpengaruh positif terhadap brand loyalty $(y)$

$H 1$ : Brand awareness $\left(\mathrm{x}_{3}\right)$ berpengaruh positif terhadap brand loyalty $(y)$

Hasil uji hipotesis dengan regresi linier berganda menunjukkan nilai signifikan sebesar 0,000 (kurang dari $5 \%$ ) atau t hitungnya sebesar 6,713 (di atas 1,96). Hal tersebut dinilai dari masingmasing indikator brand awareness seperti recall, recognition, purchase decision dan consumption. Dengan demikian pada kasus ini dapat disimpulkan bahwa brand awareness berpengaruh positif signifikan terhadap brand loyalty, artinya semakin kuat brand awareness maka brand loyalty konsumen cenderung akan semakin tinggi.

\section{Pengaruh Kemasan, Kewajaran harga, Brand Awareness Terhadap Brand Loyalty}

Hipotesis keempat bertujuan untuk menguji pengaruh kemasan, kewajaran harga dan brand awareness secara serempak terhadap brand loyalty yang dituliskan sebagai berikut :

$H O$ : Kemasan, kewajaran harga dan brand awareness $\left(\mathrm{x}_{4}\right)$ tidak berpengaruh positif signifikan terhadap brand loyalty $(y)$

$H 1$ : Kemasan, kewajaran harga dan brand awareness $\left(\mathrm{x}_{4}\right)$ berpengaruh positif signifikan terhadap brand loyalty $(y)$ 
Tabel 6 Hasil Uji F

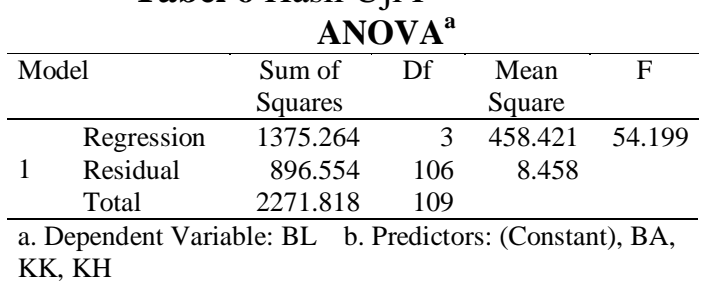

Hasil pengolahan menunjukkan nilai indikator berupa nilai $\mathrm{F}$ sebesar 54,199. Secara statistik nilai $F$ dipakai untuk menunjukkan apakah variabel independen (X) secara bersama-sama memberikan pengaruh secara signifikan terhadap variabel dependen (Y).

Melalui hasil perhitungan menggunakan Microsoft Excell, diketahui nilai $\mathrm{F}$ tabel adalah 2,69 $(\alpha=5 \%$, df $1=\mathrm{k} 1, \mathrm{df} 2=\mathrm{n}-\mathrm{k}-1)$ maka dengan demikian $\mathrm{F}$ hitung 54,199 > F tabel 2,69 yang artinya bahwa ketiga variabel independen yaitu kemasan, kewajaran harga dan brand awareness secara bersama-sama memberikan pengaruh positif signifikan pada variabel dependen yaitu brand loyalty. Artinya, adanya kemasan yang semakin berkualitas dengan harga produk yang semakin wajar disertai brand awareness yang semakin tinggi akan meningkatkan brand loyalty Wisatawan Nusantara terhadap merek kue Kartika Sari.

\section{IMPLIKASI MANAJERIAL}

Berdasarkan hasil penelitian, diketahui pada persamaan regresi terdapat nilai konstanta negatif $(-2,479)$. Hal ini menunjukan bahwa tanpa adanya kemasan, harga yang wajar dan brand awareness maka konsumen Kartika Sari sudah beralih (switch) ke merek lain. Dengan kata lain Wisatawan Nusantara sangat memperhatikan faktor kemasan, harga yang wajar dan brand awareness. Oleh karena itu maka pihak Kartika Sari perlu memperhatikan beberapa hal penting yang memperngaruhi brand loyalty Wisatawan Nusantara pada Kartika Sari Bandung, yaitu :

1. Kemasan

Hasil penelitian menyatakan bahwa semakin tinggi kualitas kemasan membuat brand loyalty yang dimiliki Wisatawan Nusantara semakin tinggi pula. Melalui pernyataan tersebut maka ada beberapa aspek pada kemasan yang dapat menjadi perhatian bagi Kartika Sari untuk menjaga kualitas kemasan, yaitu :

- Sisi bahan : Melalui hasil kuesioner terdapat keluhan responden mengenai bahan kemasan yang mudah penyok atau rusak karena ditumpuk atau tertindih dus bolen lainnya. Pihak Kartika Sari dapat lebih meperhatikan kualitas bahan yang dipakai dengan melakukan quality control kemasan terlebih dulu sebelum digunakan. Cara lainnya dengan melengkapi label kemasan dengan informasi mengenai tumpukan maksimum kemasan.

- Sisi warna : Melalui hasil kuesioner terdapat saran dari responden agar warna kemasan lebih bervariasi. Menurut sebagian responden kemasan Kartika Sari akan lebih menarik lagi jika dilengkapi warna baru. Hingga saat ini kemasan pada beberapa produk lama Kartika Sari seperti bolen coklat dan bolen keju masih memakai warna lama. Untuk lebih meningkatkan daya tarik pada Wisatawan Nusantara Kartika Sari dapat mencoba warna baru, misalnya warna putih dikombinasikan dengan warna gold untuk menciptakan kesan yang lebih berkelas dibandingkan pesaing atau melakukan pembedaan warna untuk masing-masing rasa bolen, misalnya : duren bolen menggunakan mayoritas warna kuning, kacang hijau bolen menggunakan warna mayoritas hijau, dan lain sebagainya. Untuk menambah variasi, kantong kresek yang selama ini menjadi kemasan secondary dapat juga memakai warna transparan sehingga lebih menarik perhatian.

- Sisi desain bentuk: Melalui hasil kuesioner terdapat saran dari responden agar bentuk kemasan lebih inovatif dan menarik. Saat ini beberapa produk lama seperti bolen keju dan bolen coklat masih menggunakan desain kemasan lama. Untuk lebih memberikan daya tarik pada konsumen, Kartika Sari dapat melakukan inovasi dengan membuat desain baru seperti misalnya mencoba sistem buka tutup kemasan dengan sistem geser pada kemasan agar lebih praktis dan menarik.

2. Kewajaran Harga

Melalui hasil kuesioner responden terdapat saran dari konsumen agar harga Kartika Sari jangan dinaikkan lagi karena jika terlalu mahal maka kemungkinan konsumen untuk beralih ke produk pesaing cukup besar. Oleh karena itu Kartika Sari perlu memperhatikan dan menjaga kewajaran harga yang ditetapkan. Selain itu konsumen akan merasa membayar harga yang wajar saat mereka menerima manfaat, kualitas, nilai dan kenyamanan yang sepadan. 
Beberapa aspek yang penting untuk diperhatikan agar dapat meningkatkan nilai kewajaran harga yaitu:

- Meningkatkan layanan toko khususnya keramahan. Melalui observasi yang sudah dilakukan ke lokasi penelitian, karyawan toko yang melayani masih perlu ditingkatkan lagi keramahannya terutama dalam hal senyum dan sapaan.

- Harga bolen Kartika Sari yang lebih tinggi dibandingkan pesaing dapat menjadi wajar pada persepsi konsumen saat adanya keunggulan fasilitas interior dan exterior (Dunne \& Lusch, 2008), misalnya dengan memperbaiki fasilitas parkir dan meningkatkan fasilitas toko. Melalui hasil penelitian diketahui bahwa terdapat keluhan responden mengenai sulitnya mendapatkan tempat parkir khususnya di lokasi Jl. H. Akbar dan Kebon Jukut. Hal ini sebaiknya menjadi perhatian bagi Kartika Sari untuk dipertimbangkan dalam rencana jangka panjang agar memiliki alokasi parkir yang lebih teratur. Untuk meningkatkan nilai kenyamanan dibandingkan pesaing, pada layout toko Kartika Sari khususnya di H. Akbar dan Kebun Jukut dapat juga dilengkapi dengan area tempat duduk khusus. Dengan adanya area tempat duduk yang nyaman, konsumen juga dapat lebih rileks saat situasi antrian toko sangat padat.

- Alternatif lainnya, Kartika Sari dapat menyesuaikan skimming price yang ada dengan menambah atribut produk yang belum dimiliki pesaing misalnya sauce untuk bolen celup, dengan kata lain bolen yang disediakan dengan sauce coklat, sauce keju, atau caramel untuk dicelup atau juga dengan menambah pilihan rasa yang belum dimiliki pesaing, misalnya bolen cappuccino, bolen tiramisu, bolen cheese milk dan lain-lain.

\section{Brand awareness}

Kartika Sari memang sudah dikenal oleh para Wisatawan Nusantara yang berkunjung ke Bandung, namun seiring dengan meningkatnya persaingan maka Kartika Sari perlu meningkatkan brand awareness-nya. Beberapa hal yang dapat dilakukan Kartika Sari untuk meningkatkan brand awareness yaitu :

- Advertising : misalnya dengan pemasangan billboard di bandarabandara nasional dan di area jalan tol dan jalan raya luar kota seperti jalan tol Bandung Jakarta, jalan raya Puncak, Lembang dan lain-lain. Adanya iklan tersebut tidak hanya dapat menciptakan kesadaran dan mengingatkan Wisatawan Nusantara tapi juga dapat mempengaruhi untuk Wisatawan Nusantara untuk membeli. Selama ini iklan atau billboard Kartika Sari masih jarang ditemui di area atau lokasi-lokasi tersebut. Media promosi yang terjadi saat ini masih sebatas word of mouth konsumen.

- Public Relation : terlibat dalam kegiatan sosial kemasyarakatan, misalnya : menjadi sponsor dalam event nasional seperti PON, Pemilu, Peduli Bencana Alam, dan lain-lain. Adanya keterlibatan dalam event tersebut selain menciptakan image yang positif dan menarik empati masyarakat tetapi juga dapat semakin meningkatkan brand awareness masyarakat dalam jangkauan yang lebih luas lagi (skala nasional).

\section{KESIMPULAN}

Hasil analisa dari penelitian ini membuktikan bahwa :

1. Kemasan berpengaruh positif secara signifikan terhadap brand loyalty, artinya kemasan yang semakin berkualitas cenderung membuat brand loyalty Wisatawan Nusantara semakin tinggi. Dengan kata lain bagi para Wisatawan Nusantara, kemasan adalah salah satu atribut yang sangat penting yang senantiasa perlu diperhatikan kualitasnya oleh pihak Kartika Sari.

2. Kewajaran harga berpengaruh positif secara signifikan terhadap brand loyalty, artinya semakin wajar harga kue yang ditetapkan Kartika Sari maka akan semakin tinggi brand loyalty Wisatawan Nusantara terhadap 
merek kue Kartika Sari. Dengan kata lain bagi para Wisatawan Nusantara, harga yang wajar merupakan salah satu faktor utama untuk membuat mereka tetap loyal pada merek Kartika Sari.

3. Brand awareness berpengaruh positif secara signifikan pada brand loyalty, artinya semakin tinggi brand awareness Wisatawan Nusantara pada merek kue Kartika Sari maka semakin tinggi pula brand loyalty Wisatawan Nusantara terhadap merek kue Kartika Sari. Dengan kata lain bagi Wisatawan Nusantara, brand awareness merupakan faktor utama yang membuat mereka tetap memilih merek Kartika Sari.

4. Kemasan, kewajaran harga dan brand Awareness berpengaruh positif signifikan terhadap brand loyalty, artinya dengan meningkatkan kualitas kemasan, kewajaran harga dan brand awareness secara bersamaan maka brand loyalty Wisatawan Nusantara juga akan meningkat. Dengan kata lain, baik kemasan, kewajaran harga dan brand awareness dinilai oleh Wisatawan Nusantara sebagai faktor-faktor yang sangat penting yang dapat mempengaruhi brand loyalty.

\section{SARAN}

Beberapa saran bagi pihak Kartika Sari di antaranya :

1. Lebih memperhatikan kualitas bahan kemasan sebelum digunakan untuk meminimalisir keluhan konsumen tentang bahan kemasan yang mudah rusak. Selain itu pada rencana jangka panjang, Kartika Sari dapat mencoba desain kemasan bentuk baru yang lebih menarik dari pesaing.

2. Menjaga kewajaran harga kue agar para Wisatawan Nusantara tidak beralih ke produk pesaing.

3. Menjangkau scoup market potential yang lebih besar dengan memasang billboard di bandara nasional dan area tol yang akan dilalui Wisatawan Nusantara. Melaksanakan aktivitas yang menciptakan image positif dan menarik empati masyarakat secara luas dengan media public relation, event and sponsorship.

Menyadari adanya keterbatasan pada penelitian ini, maka saran bagi penelitian selanjutnya sebaiknya melanjutkan hasil penelitian ini dengan meneliti aspek-aspek lain dalam brand equity yang berkaitan dengan brand loyalty seperti perceived quality dan brand association. Selain itu sebaiknya hasil penelitian ini juga dapat dilanjutkan dengan metode kualitatif untuk mengetahui perspektif perusahaan tentang kualitas kemasan, kewajaran harga, brand awareness dan brand loyalty di Toko Kue Kartika Sari.

\section{DAFTAR PUSTAKA}

Aaker, D. (2000). Building Strong Brands, Free Press. New York.

Augusty, F. (2006). Metode Penelitian Manajemen. Semarang : Badan Penerbit Universitas Dipenogoro.

Consuegra, D., Molina, A., \& Esteban, À. (2007). An Integrated Model of Price, Satisfaction and Loyalty: an Empirical Analysis in Service Sector. Journal of Product \& Brand management.

Dhurup, M., Mafini, C \& Dumasi, T. (2014). “ The impact of packaging, price, and brand awareness on brand loyalty: Evidence from the paint retailing industry, "Acta Commercii 14 (1), Art.

Durianto, D., Sugiarto dan Budiman, L. (2004). Brand Equity Ten, Strategi Memimpin Pasar. Jakarta. PT Gramedia Pustaka Utama.

Ghozali, I. (2009). Aplikasi Analisis Multivariate Dengan Program SPSS, Edisi Keempat, Penerbit Universitas Diponegoro.

Hartono, K. (2012). "Pengaruh Materialism, Compulsive Buying Dimoderasi Time Affluence Terhadap Subjective Well Being Studi Kasus Pada Produk Sepatu Charles And Keith Di Bandung."

Iin, A, I. (2009). Entrepreneurial marketing for small and medium enterprises business. Jakarta.

Jaswin M. (2008). Packaging Materials and its Applications. Jakarta: Indonesian Packaging Federation

Jogiyanto. (2007). Metodologi Penelitian Bisnis : Salah Kaprah dan PengalamanPengalaman. Penerbit: BPFE, Yogyakarta.

Kotler, P., \& K.L Keller. (2004). Marketing Management. New Jersey : Prentice Hall.

Kotler, P., \& K.L Keller. (2005). Marketing Management. New Jersey : Prentice Hall.

Kotler, P., \& Armstrong. (2010). Marketing Management. New Jersey: Prentice Hall 
Margono, S. (2003). Metodologi Penelitian Pendidikan, Jakarta: Rineka Cipta

Marchaela. (2015). 10 Oleh-oleh Khas Bandung yang Terkenal.www.anekatempatwisata.com

Purnomo, R. (2015). Sejarah Kartika Sari. www.kartikasari.com

Rangkuti, F. (2002). The Power of Brand. Jakarta: PT Gramedia Pustaka Utama

Rahyuda, C.(2009). Pengaruh Kewajaran Harga, Citra Perusahaan Terhadap Kepuasan dan Loyalitas Konsumen.

Steward, M. (2004). Brand Dictionary,Kamus Pemasaran. Terjemahan A. Hasyimi Ali. Jakarta: PT Rineka Cipta.

Stokes, D. (2000). "Entrepreneurial Marketing : A Conceptualization From Qualitative Research."

Sugiama, G. A. (2008). “ Metode RisetBisnis dan Manajemen. Guardaya Intimarta, Bandung.

Suresh, S., Mohanam, P. \& Naresh, G. (2012). "Brand success redefined: An analysis of the interrelationship among various brand dimensions," Psychological Research 2(1).

Tjiptono, F. (2002). Startegi Pemasaran Modern. Penerbit Andi. Yogyakarta

Uma, S. (2009). Research Methods For Business. Edisi 4, Buku 1, Jakarta: Empat.

Wahyuni, T. (2015). Bandung Kota Terfavorit Wisatawan. www.cnnindonesia.com

Xia, L., Monroe, K.B \& Cox, J.L. (2004). The price is unfair! A conceptual framework of price fairness perceptions, Journal of Marketing. 